\title{
Beer-trail Maps and the Growth of Experiential Tourism
}

\author{
Alison E. Feeney \\ Shippensburg University \\ aefeen@ship.edu
}

A well-designed map can influence tourists' activities, yet tourist maps and their designs remain under-examined in the cartographic literature. Today, many Americans are traveling to indulge in new food and drink experiences, which can potentially increase revenues in other related tourist amenities. Specifically, travel to craft breweries is increasing, and tourism agencies throughout North America promote beer trails. This study identified 100 beer trails promoted by official tourism agencies, inventoried how many of those trails' marketing materials included a map, and evaluated those maps using Quantitative Content Analysis (QCA) for common design elements. The overall goal of the project was to determine if the maps featured only the breweries or if they promoted visiting additional experiential activities that contributed to the creation of a sense of place, and that in turn, may provide potential benefits to the travel destination.

The results found that tourism agencies aggressively advertise local breweries, but the maps developed for beer trails significantly underutilize effective cartographic principles and do not promote other regional activities. Most trail maps were made with Google Maps, an effective tool for navigation, but one that often produced unbalanced layouts and did not use symbology to effectively emphasize tourist activities. Additionally, Google Maps tends to suggest travel on main roads or highways rather than smaller back roads that are more likely to host additional local activities. A limited number of maps were artistically designed to focus the viewer's attention on the regional landscape and other available activities, but were designed in a highly generalized, cartoon-like style. Only two agencies mapped breweries along with suggested routes and additional activities using symbols, colors, fonts, and pictures appropriate for the age demographic of their market audience.

KEYWORDS: beer trails; craft breweries; tourism; quantitative content analysis; map design

\section{INTRODUCTION}

TOURISM IS A GLOBALLY IMPORTANT, dynamic industry. It constantly changes based upon shifts in the popularity of different activities and interests, economies, politics, and the perceived value or condition of the destination. One of the recent changes in the US industry is the increased number of Americans travelling to places where they can sample the food and drink from different regions. Not only can they consume the product close to where it is made, but they can also experience local traditions and customs. One such type of tourism destination is the craft brewery. The number of people traveling to enjoy a beer, see how it is made, learn something about the process, and even socialize with the brewer is on the rise. Craft beer tends to be consumed by a particular demographic, one that has some disposable income, available recreational time, and is likely to seek out experiential tourism activities (McLaughlin, Reid, and Moore 2014). “Tapping” into this consumer market offers regions surrounding brew trails the potential to create experiential tourist destinations and generate additional income.

This study examined how often maps were used to encourage tourism surrounding prominent beer-producing regions in North America. Among those areas that did utilize a map, Quantitative Content Analysis (QCA) was used to determine if the maps were purely wayfinding tools, or whether they displayed other tourist attractions to market the surrounding region. Of the maps that did 
promote the broader region, I asked what type of symbolization and design techniques were used. The overall goal of the project was to assess if these tourism maps are contributing to the creation of a sense of place, and in turn, providing potential benefits to travel destinations.

\section{IMPORTANCE OF TOURISM MAPS}

THE TOURISM INDUSTRY IS highly competitive, with destinations being sold as branded, marketed products. Monmonier (1996) states that cartography and advertising can promote a clear, favorable image, and that marketing maps can be an effective, eye-catching tool. All maps have some bias (Wood 1992), but some can be more persuasive than others. Maps can greatly influence the success of a region (Ashworth 2011), for they play a significant role in how we discover, learn, and communicate information about the world. While maps should be fundamental tools used in planning a trip (Richmond and Keller 2003), they are an underutilized resource in tourism (Bailey et al. 2012). Bailey et al. (2012) found that although most visitors use maps to acquire spatial knowledge, many maps in informational brochures and at tourist kiosks suffer from poor design.

Tourism maps and their design remain under-examined in the literature of tourism geography and cartography. Unlike thematic or cadastral maps, Muehlenhaus (2011a) stated that persuasive maps are not well studied in the cartographic literature, and argued that the goal of persuasive tourist maps is different than more scientifically-oriented maps. Del Casino and Hanna (2000) argued that this omission is in part because tourism maps are seen as blatant forms of advertising, with great aesthetic and cartographic license. Grant and Keller (1999) found the neglect of tourist mapping in the academic literature surprising due to the importance of promoting destinations, and a map's ability to contribute to both the production and perception of space. They argued that the fields of recreation and tourism could greatly benefit by improving their maps to help create a sense of place and regional attachment to the landscape. Hojman and Hunter-Jones (2012) found that most tourists conscientiously follow suggested routes, travel to recommended areas, and seek out other consumption activities and social experiences that are advertised. Maps, therefore, could be used to channel desired tourist activities.

The content and structure of tourism maps changes frequently. Increasingly, people are using websites, social media, and smart phone apps to plan and book trips and excursions (Fuggle 2016); such digital technologies remove physical barriers and eliminate printing and distribution costs. Along with these recent shifts from printed brochures to online maps, the types of activities promoted by such maps and the appeal of particular destinations continue to change over time. Martin (2011) provided historic evidence that representations of idealized activities and images changed over three decades of American tourism maps in the Caribbean. Schnell (2011) examined recent tourism guides from North America. Using quantitative content analysis, he found notable changes from 1993 to 2008 , including an enormous expansion in the promotion of activity-based experiential tourism centered on local food and agriculture. Usage of the keywords "local" increased tenfold, "agriculture" tripled, and "farm" or "farmers" quadrupled in tourist guides from the United States.

\section{GROWTH IN EXPERIENTIAL TOURISM}

TOURISM IS ONE OF THE fastest-growing businesses in the world, and many tourists, particularly Americans, enjoy their recreational time by traveling to places of food and beverage production to seek out new palate experiences (Veeck, Che, and Veeck 2006). Variations in the language used to describe these experiences, such as gastronomic tourism, food tourism, agritourism, wine tourism, and beer tourism reflect a focus on the unique types of cultural experiences that a specific location's food and drink can provide. Travelers journey to farms, vineyards, breweries, festivals, trade shows, and farmers markets to indulge their palate, while also immersing themselves in local traditions, cultures, economies, and communities. This experiential consumption creates enjoyment for the traveler that extends past the basic intake of food and drink to include education at the source of production, while 
travelers also glean pleasure from the regional environs, recreational activities, and cultural lifestyles (Hojman and Hunter-Jones 2012).

The growth in experiential tourism corresponds to the larger farm-to-table movement. Food tourism fuels the notion that there is more to food than food itself, and that taken out of its geographic context, it loses its meaning. Schnell (2011) suggested that part of this growth can be attributed to recent food scares, such as mad cow disease, food recalls, and E. coli outbreaks. Meanwhile, Colton and Bissix (2005) stressed that the growth is a result of tourists seeking alternatives to patterns of hedonistic consumption. Additionally, with growing concerns of conflict, terrorism, and global economic meltdowns, many travelers yearn for an idyllic, rural vacation. This sector of the tourism industry feeds on nostalgia for the vanishing rural past, and on many people's affection for the countryside as our society becomes more urbanized. This growth of tourism can be seen as an extension of the neolocal movement described by Tuan (1991), as a conscious commitment to preserve and support local economies and social networks in an era of mass production and global consumption.

Many positive benefits come from experiential tourism. It has been hailed as a vehicle for regional development and strengthening local production (Everett and Slocum
2013). Tourism can potentially raise local incomes while offering consumers local products, education, recreation, and socializing opportunities. The notion of eating locally suggests unique choices produced in an ecologically friendly, sustainable way and implies empowering self-sufficient people. The region surrounding such tourist activities can potentially experience increased revenues for other related businesses such as hotels, gift stores, and gas stations. Ferreira and Muller (2013) described the growth in wine tourism as a driver of economic and social development in rural areas because of the collective lifestyle experiences.

Wineries, distilleries, and breweries are at the forefront of this growing industry. Parts of Europe and North America, such as Bordeaux, France; Tuscany, Italy; and the Napa Valley, California, have established themselves as experiential tourist regions, but Carmichael and Senese (2012) reported that lesser-known areas are also seeing rapid growth in the tourism and experiential sectors. Halladay (2012) reported that in 2012, Virginia's wineries experienced a $106 \%$ increase in tourism since 2005 , contributing $\$ 747$ million annually to the Commonwealth, Kentucky's Bourbon Trail reported over 450,000 visitors in one year, and the online travel company Viator saw a $50 \%$ increase of wine tour sales in 2011. Viator also reported that craft beer tours are becoming more abundant.

\section{THE GROWTH OF CRAFT BEER AND ITS CONNECTION TO TOURISM}

BEER HAS BEEN AN IMPORTANT consumption commodity in the United States from its early European settlement to the present day (Feeney 2015); in recent decades, marketing and advertising have had significant impacts upon the economic success of the industry. Following Prohibition, the American beer industry experienced steady growth, along with the consolidation of breweries, and entered an era of mass production. By 1950, the top five brewing companies held $24 \%$ of the market and by 1975, they held 75\%, with Anheuser-Busch, Miller, and Schlitz-Stroh leading the nation (Batzli 2014). As the industry began to plateau in the 1970s, marketing and advertising became essential. Media advertising expenditures increased fivefold from 1977 to 1998, with brewers spending $\$ 752$ million per year (Wilcox 2001). Advertising expenditures had a significant impact on market shares, and studies showed that creative commercials played a critical role in consumer behavior.
Today, Americans consume on average 20.3 gallons of beer per year, and although large mass-produced brands still hold the market, an increasing number of consumers are selecting craft beers (Reid, McLaughlin, and Moore 2014). Craft breweries are considered small and independent, use traditional brewing methods, and are known for their innovative flavors. The industry exploded from only eight craft breweries in 1980 to almost 2,500 in 2013, with $98 \%$ of all US breweries being small and independent (Hoalst-Pullen et al. 2014). In June 2013, craft breweries produced $7.8 \%$ of volume but $14.3 \%$ of dollar sales. Whitwell (2014) reported that this was a $16 \%$ increase in volume for craft beers, versus a $1.7 \%$ decrease for the mass-produced brands. Budweiser remains the third most popular beer in the United States, but declined in volume of sales 6\% annually between 2008 and 2013 (Felberbaum 2015). 
Del Buono (2015) argued that craft beer has gone from a niche market to a cultural phenomenon, and is one of the fastest-growing segments in the alcoholic beverage industry. People are willing to travel to experience drinking a beer at the place of production because craft breweries conspicuously promote traditional, wholesome brewing styles, advertise their use of local ingredients, demonstrate their connections to clean, local water sources, and name their beers in relation to local folklore and cultural events. Craft breweries clearly match their identities with their location, and it is nearly impossible to consume a craft beer without some awareness of its origin and cultural expression (Caroll and Swaminantham 2000).

Craft beer is an ideal product for the experiential tourism industry to market because of its ties to local geography, and it is an important product in the tourism market because it is often consumed by a specific demographic (McLaughlin, Reid, and Moore 2014). The typical craft beer drinker is a well-educated, white male earning at least $\$ 75,000$ annually. This group tends to have plentiful disposable income, spends money on consuming food and drink, and enjoys the prestige factor that is associated with craft beer. Mowen, Graefe, and Graefe (2013) found that craft beer drinkers are adventurous, try new beers, and search out restaurants with craft beers. Their research also found that this group included many active tourists. Over a twelve-month span, the average craft beer drinker reported that they visited 30 craft breweries, made two 50-mile or greater trips that involved stopping at a craft brewery, and attended at least two craft beer festivals.

The growth of craft breweries across the United States is geographically uneven. The largest concentration of breweries is in California, the Pacific Northwest, and Colorado, with a secondary hub near the Great Lakes, and a third concentration in the Mid-Atlantic States (HoalstPullen et al. 2014). Strong local pride and ties to historic immigrant settlement patterns are often cited as the reasons for growth in these areas, while religion and legal restrictions on home brewing that have only recently been removed can be linked to the scarcity of craft breweries in the South. Although analysis shows that the size of population heavily influences the number of breweries, Reid, McLaughlin, and Moore (2014) controlled for total population and found that Vermont had the highest number of breweries per capita, probably due to tourism. Similarly, Baginski and Bell (2011) used step-wise regression models and identified areas with large, tourist-based economies, such as Charlottesville, Virginia; Asheville, North Carolina; Myrtle Beach, South Carolina; and southern coastal Florida as having well above the expected number of craft breweries based upon their location and total population size. These studies demonstrate that craft breweries are a big draw for tourists, and that they can contribute to the potential success of a tourism region.

\section{METHOD FOR EXAMINATION OF}

FOR THIS STUDY, I inventoried beer trails promoted by official tourism agencies, and tallied how many of those trails included a map. Because most travel plans begin with the internet, I used common search engines to identify beer trails in regions with high concentrations of craft breweries. The top five search engines, Google, Bing, Yahoo, Ask, and Aol (eBizMBA Guide 2016) were used to identify beer trails from official tourism offices, brewery associations, and regional partnerships in areas with a high concentration of breweries. Searches included combinations of the following terms: craft beer, breweries, ale, lager, food, trails, destinations, vacations, trips, and experiences. Repeated searches looked for beer trails in regions of decreasing size, starting with North America and the United States, followed by regions, such as the Pacific Northwest, Northeast, or Midwest, followed by individual state-level searches such as California, Oregon, and

\section{EXISTING BEER TRAIL MAPS}

Pennsylvania. Local areas, such as the Willamette Valley, Hudson Valley, and greater Philadelphia region were then searched. Finally, the most local scale was searched to identify beer trails in individual cities such as Portland, San Diego, Boulder, Grand Rapids, Asheville, and Pittsburgh.

Both descriptive statistics and qualitative measures were employed to examine the inventoried maps. Suchan and Brewer (2000) have suggested several qualitative methods that are valid for scientific inquiry, and have argued that qualitative research can assist cartographers to uncover patterns of inter-relationships. Additionally, Muehlenhaus (2011b) provides a critical review of the benefits of quantitative content analysis (QCA), and stresses its strength in examining changes in thematic map design. QCA allows for the construction of quantitative measures of particular 
graphic elements and the comparison of different mapped traits. For QCA to be valid, research questions must be determined prior to study, and explicit codes must be developed and rigorously applied to all maps, so results can be replicated.

The goal of this project was to determine how many tourism brewery trails include maps, and of those that do, what design techniques are common? An additional question was whether these maps contribute to the creation of a sense of place, and in turn provide potential additional benefits to the travel destination. The QCA codes, therefore, focused on these questions. The first set of codes determined if the trail included a map (yes or no) and the scale of the map (local, regional, statewide, or national).

The next set of codes focused on the purpose of the map and its intended use. Ideally, interactive maps, such as those created in Google Maps, should be designed around the purpose for which the user wants to use the map, and can additionally offer directions from point $\mathrm{A}$ to point B. Yet, as Roth, Ross, and MacEachren (2015) indicate, many interactive maps have shortcomings, such as incorrect classification schemes, illogical symbolization, or even inaccurate information. This second set of QCA codes queried whether the map was a static product or an interactive map, and evaluated each map for its intended use (highly generalized, trip planning stage, or wayfinding and navigation). A highly generalized map was defined as a map that provided few locational clues, for example, one or two place names or one or two stylized roads.

Several QCA codes focused on map design concepts commonly defined in the cartographic literature (MacEachren 1994), such as layout (balanced or uneven) and point symbols (iconic or geometric). A map has an incredible ability to emphasize particular features (Monmonier 1996), and several codes focused on whether symbols promoted additional experiential tourism activities, encouraged travel on specific routes, or contributed to creating an overall feel of the destination. Further codes recorded the number of themes (a numeric count as defined in the legend or title), categorized transportation routes depicted in the map (all roads mapped similarly, symbolized main travel routes, or exaggerated the beer trail location), and noted the inclusion of pictures or graphics.

\section{RESULTS}

Craft beer tourism and brew trails are thriving, are prominently promoted by tourism agencies, and can easily be discovered online. A web search for "beer trails" yields over 25 million results, whereas adding a specific location to the search, such as "brew trails North America" or "beer trails Pacific Northwest," returns over 2.5 million results. Even at a state- or city-wide level, most searches returned over 500,000 results. Because this study focused on trails that were developed to increase tourism, only trails designed by local, state, or regional tourism agencies and guilds were used, although I found many additional trails that were suggested by newspapers, magazines, and personal blogs.

The term "trail" is used loosely in many tourism webpages. Many local-, regional-, and state-level tourist bureaus refer to a "beer trail," but do not designate a path or geographic structure that encourages directed movement. Due to this sometimes vague use of the term, only officially-designated beer trails that followed an identifiable path were included in this study. One hundred such trails were identified for this project, which is a strong, representative sample of the types of beer trails advertised for tourism purposes. Table
1 inventories some of the characteristics of these trails, and the list of all trails appears in the Appendix.

The first few codes of the QCA focused on the existence of a map, the geographic scale of the map, and its intended use. Twelve tourist bureaus have created trails that proudly promote their breweries, market the quality of their products, demonstrate their commitment to sustainable business practices, and show off the appeal of their dining environs, without providing any maps or directions. For example, travelindiana.com's (n.d.) slogan is "Experience Authentic Indiana," and a main section of their website promotes the "South Shore Brewery Trail"-nineteen breweries are described, but no map is included. Similarly, the Inland Northeast Ale Trail (Visit Spokane 2016) offers a color brochure depicting mountains and trees and the logo of each brewery, but no map. However, the remaining 88 beer trails did include a map, and I analyzed the characteristics of their marketing materials. Roughly an equal number of maps were identified at the local, regional, and statewide scales $(32,30$, and 25 , respectively), along with one national map presented by Visit USA (2016). 


\begin{tabular}{|c|c|c|c|c|c|}
\hline \multirow{2}{*}{ Scale } & \multicolumn{2}{|c|}{ Presence of a Map } & \multirow{2}{*}{$\begin{array}{l}\text { Percent of trails } \\
\text { with maps }\end{array}$} & \multirow{2}{*}{ Intended design use } & \multirow{2}{*}{$\begin{array}{l}\text { Percent of maps } \\
\text { with interactivity }\end{array}$} \\
\hline & No Map & Map & & & \\
\hline \multirow{3}{*}{ Local } & \multirow{3}{*}{5} & \multirow{3}{*}{32} & \multirow{3}{*}{$86.5 \%$} & $\begin{array}{c}\text { Highly generalized } \\
3(9.3 \%)\end{array}$ & \multirow{3}{*}{$16(50 \%)$} \\
\hline & & & & $\begin{array}{l}\text { Planning } \\
6(18.7 \%)\end{array}$ & \\
\hline & & & & $\begin{array}{l}\text { Wayfinding } \\
23(71.8 \%)\end{array}$ & \\
\hline \multirow{3}{*}{ Regional } & \multirow{3}{*}{4} & \multirow{3}{*}{30} & \multirow{3}{*}{$88.2 \%$} & $\begin{array}{l}\text { Highly generalized } \\
5(16.6 \%)\end{array}$ & \multirow{3}{*}{$15(50 \%)$} \\
\hline & & & & $\begin{array}{l}\text { Planning } \\
10(33.3 \%)\end{array}$ & \\
\hline & & & & $\begin{array}{l}\text { Wayfinding } \\
15(50 \%)\end{array}$ & \\
\hline \multirow{3}{*}{ Statewide } & \multirow{3}{*}{3} & \multirow{3}{*}{25} & \multirow{3}{*}{$89.2 \%$} & $\begin{array}{l}\text { Highly generalized } \\
3(12.0 \%)\end{array}$ & \multirow{3}{*}{$15(60 \%)$} \\
\hline & & & & $\begin{array}{l}\text { Planning } \\
5(20.0 \%)\end{array}$ & \\
\hline & & & & $\begin{array}{l}\text { Wayfinding } \\
17(68.0 \%)\end{array}$ & \\
\hline National & 0 & 1 & $100 \%$ & $\begin{array}{l}\text { Planning } \\
1(100 \%)\end{array}$ & $1(100 \%)$ \\
\hline Total & 12 & 88 & $88 \%$ & & $47(53.4 \%)$ \\
\hline
\end{tabular}

Table 1. Inventory of official tourism beer trails categorized by scale and use.
The scale of the map has no apparent relationship with its intended use; approximately onehalf to two-thirds of the maps at each scale were designed for wayfinding purposes, with the majority of those being interactive maps. Google Maps, by far the most common tool used to map beer trails regardless of their geographic extent, was involved in $53.4 \%$ of the trails in this study. This includes the North Carolina Craft Brewers Guild's (n.d.) "North Carolina Beer Trail," the Adirondack Regional Chambers of Commerce's (n.d.) "Adirondack Craft Beverage Trail and Map," Discover Lehigh Valley's (n.d.) "The Lehigh Valley Ale Trail," and "The Columbus Ale Trail," by Experience Columbus (n.d.). All of these trail maps use simple pins placed on a Google basemap.

Several visitor bureaus provide an overview of the breweries in an entire area, while using Google Maps to provide more detailed directions, such as the examples seen in Figure 1. Visitphilly.com, the official visitor website for the Greater
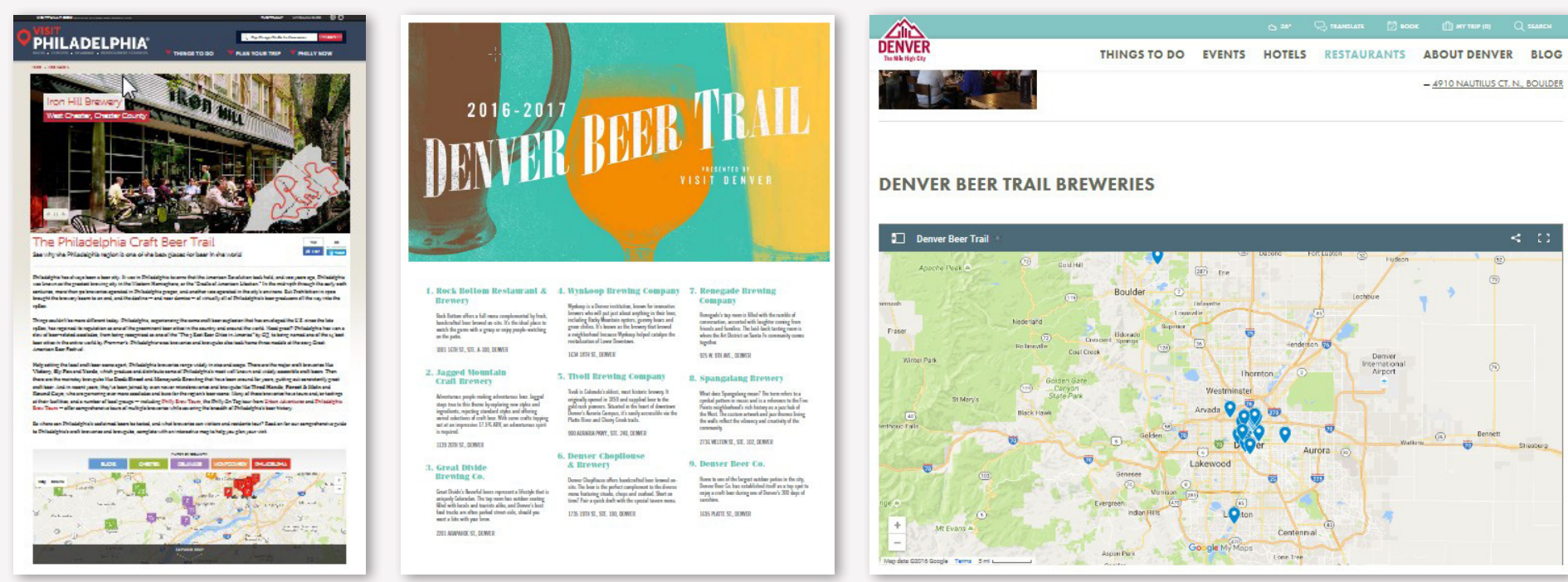

DENVER BEER TRAIL BREWERIES

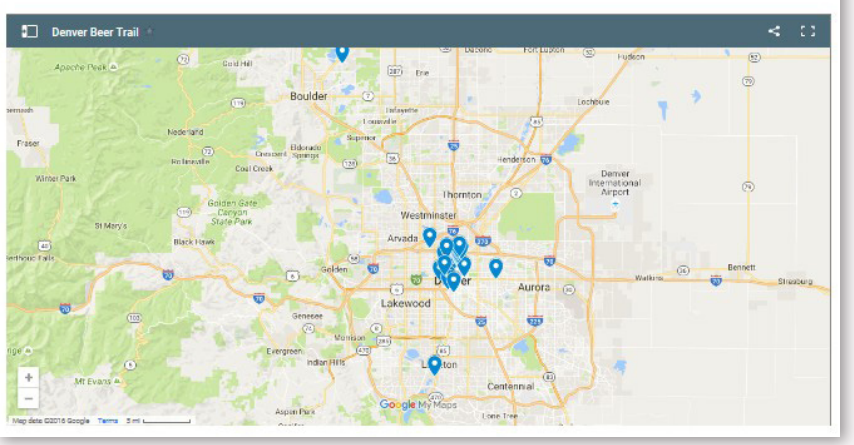

Figure 1. Examples from VisitPhilly and Visit Denver used Google Maps to display beer trails. 
Philadelphia area, describes how beer was historically important to the city, and how today the area is thriving in the new craft brewery era. They have created the "Philadelphia Craft Beer Trail," depicted as a red path on a light grey background with neither roads nor directions. It is presented on their website amongst rotating pictures of all the breweries, while specific directions to individual breweries are provided by Google Maps.

Visit Denver works with the City of Denver and the Colorado Tourism Department to develop economic benefits for the city and its community. They have created the "Denver Beer Trail," promoting over 100 breweries and brew pubs (Visit Denver, n.d.). The downloadable version lists only the addresses with no map. The website has each brewery, links to individual business websites, and a Google map displaying all breweries with simple blue pin markers.

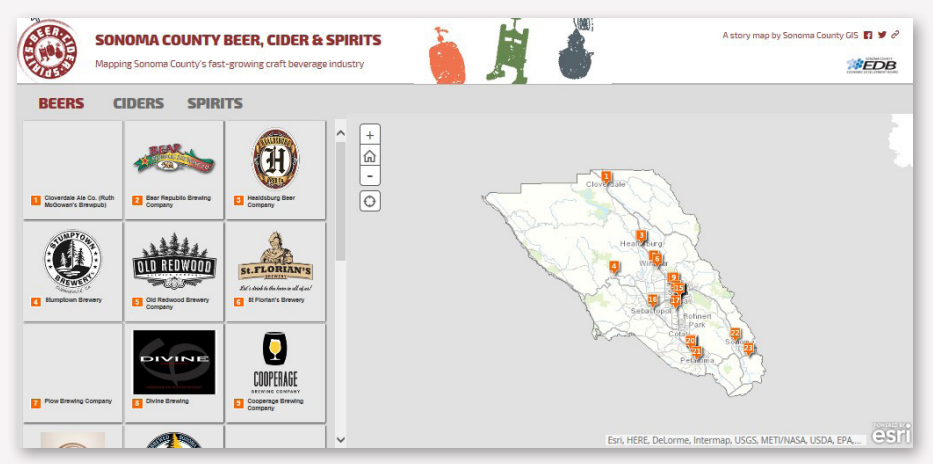

Figure 2. Esri story map representing Sonoma County's beer, cider, and spirits producers.

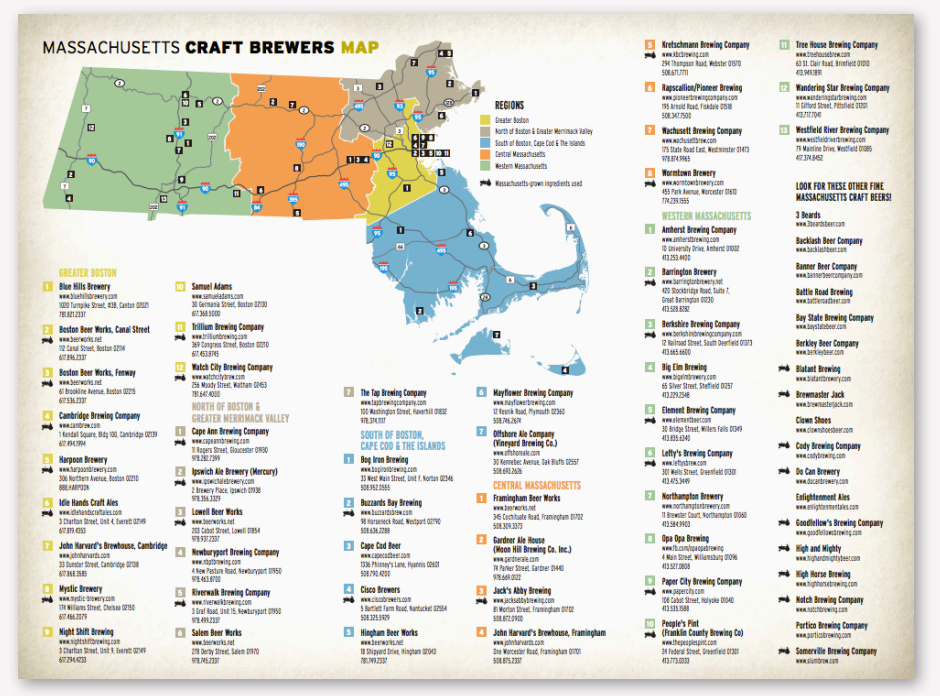

Visit California (2017) has a major section of their website devoted to beer tourism, and claims that it is a beer-lover's paradise with over 500 breweries. It separates the breweries into different regions, but does not have an actual trail or designated map. A few of the regions within the state do have trail maps. For example, the Sonoma County Tourism website (Sonoma County GIS, n.d.) has a twoday suggested itinerary for exploring the two dozen operating breweries. They created an Esri Story Map that allows viewers to display the county's beer, cider, and spirits producers interactively, and proudly advertises the fast-growing industry in its subtitle (Figure 2). The map itself is a general locator map with only major highways and cities represented, but no additional tourist activities or attractions.

After wayfinding, the most common use of the trail maps was for trip planning. Maps that fell into this category were those that presented a group of breweries with enough locational clues to organize a trip, but not enough information to actually travel or navigate to a destination without the assistance of another map. Planning maps were found at all scales. The Massachusetts Office of Travel and Tourism (2014) encourages people to grab a beer and claims that "mapping all their breweries together makes trip planning a whole lot easier." Their website describes how many of the breweries use fresh ingredients such as apples, blueberries, maple syrup, and cranberries from local farms, and how many of them are located in quaint buildings or scenic places, but does not represent these characteristics on the map (Figure 3). Similarly, the Wyoming Beer Trail (2016) provides the relative location

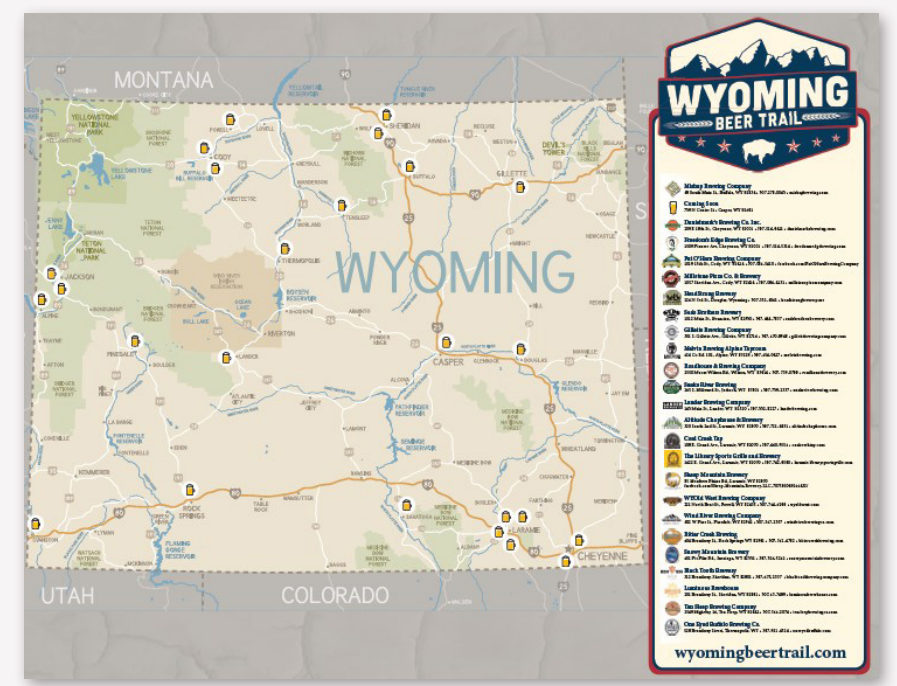

Figure 3. Example of trip planning maps, the Massachusetts Craft Beer Trail and the Wyoming Beer Trail, where the viewer can organize locations into their own trip, but needs to use additional sources to navigate to individual breweries. 

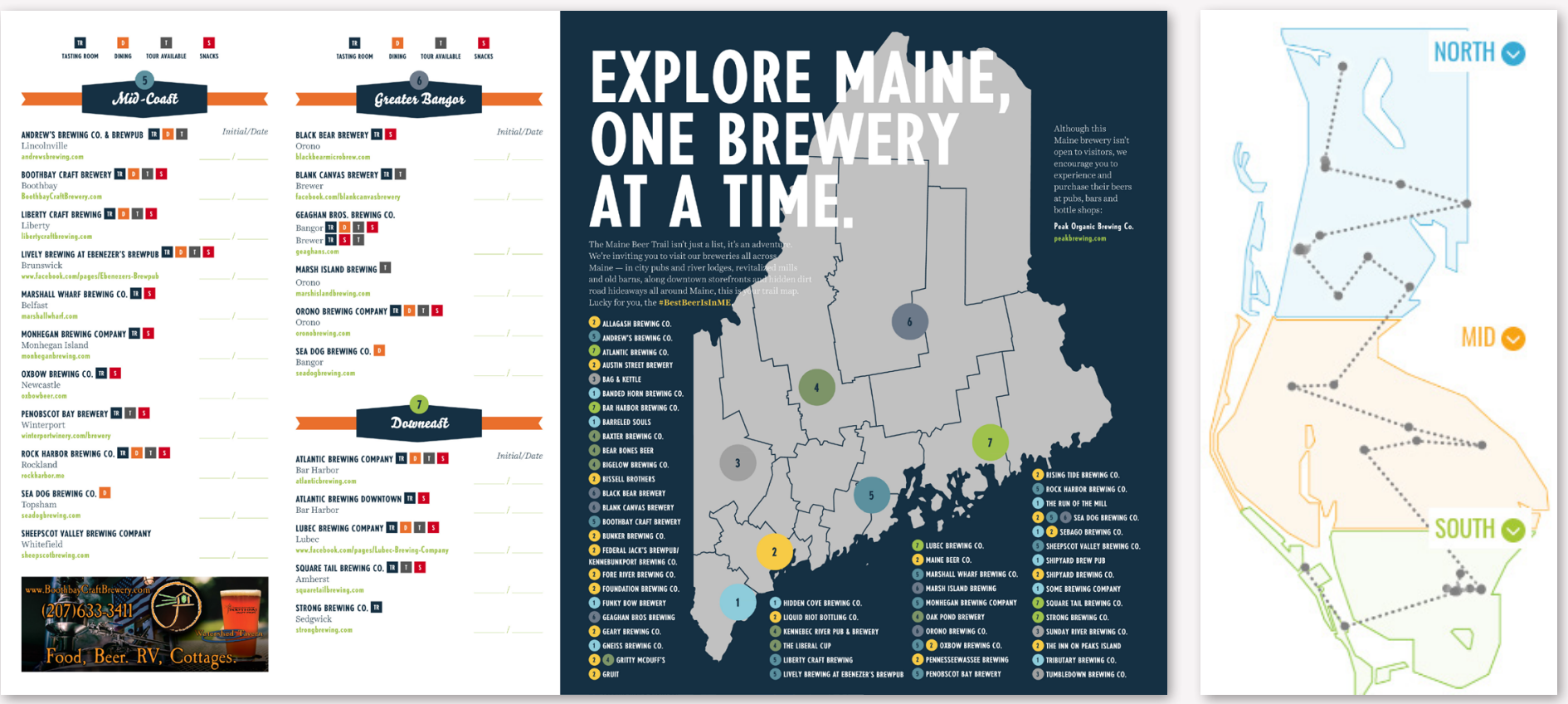

Figure 4. The 2013 Maine Beer Trail and the Gulp Coast: St. Petersburg/Clearwater Craft Beer Trail display highly generalized locations that offer limited trip planning ability and require additional maps and information to plan a trip and navigate to breweries.

of breweries on a state-wide map, with main roads and towns identified.

Only a few maps at each scale were highly generalized and served attention-grabbing, marketing purposes rather than planning or navigational purposes. Several tourism agencies give an overview of all their breweries with very little description and few locational clues. The Maine Office of Tourism (2016) website has a page titled "The Maine Beer Trail," which describes the history and growth of the state's brewery industry. It promotes the state's fifty craft breweries and highlights several of them with online links, but no map. However, the Maine Brewers' Guild (2013) created “The Maine Beer Trail,” which lists every brewery in the state and color codes the breweries by their region (Figure 4, left). Their website describes the fresh, hand-crafted quality of the beer, and offers an incentive rewards program to visit each brewery. At a local level, The
Gulp Coast: St. Petersburg/Clearwater Craft Beer Trail (Visit St. Petersburg/Clearwater 2016; Figure 4, right) divides the community into three regions and provides dots and a connected path, but has no names of breweries, locations, or roads on the map.

The next set of codes for the QCA focused on the layout and symbology of the trail maps. The overall map layout was determined to be balanced or uneven based upon the points of interests, placement of any additional features or pictures, and the place of any title, legend, or ancillary information. Symbol types, generalization or exaggeration of suggested travel routes, overall feel of the map, and number of themes were tabulated. Figure 5 displays the results.

With over half the maps being built upon Google Maps and using little additional cartographic design, the

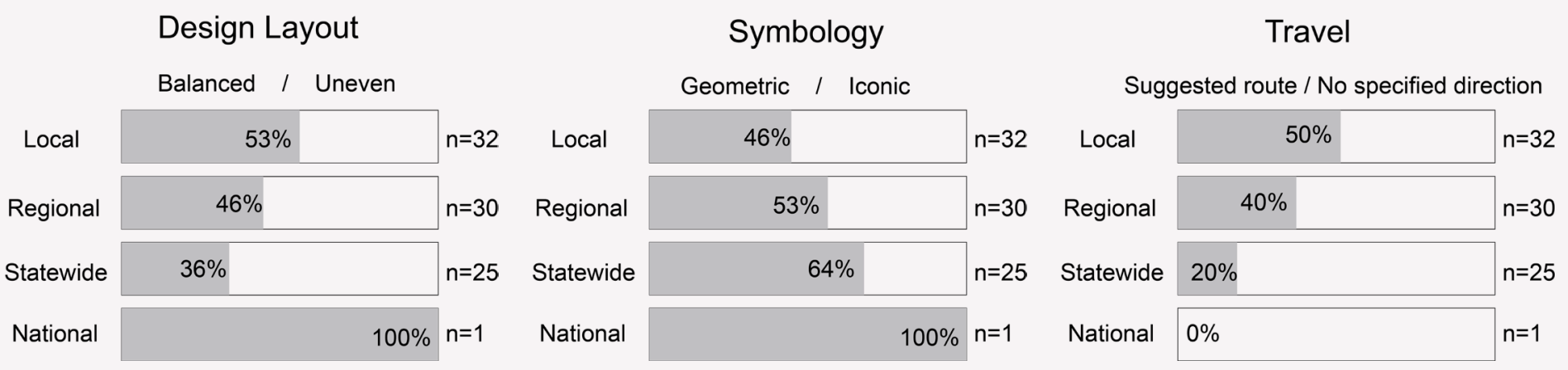

Figure 5. Results of the 88 ale trail maps by scale and layout/symbology codes. 


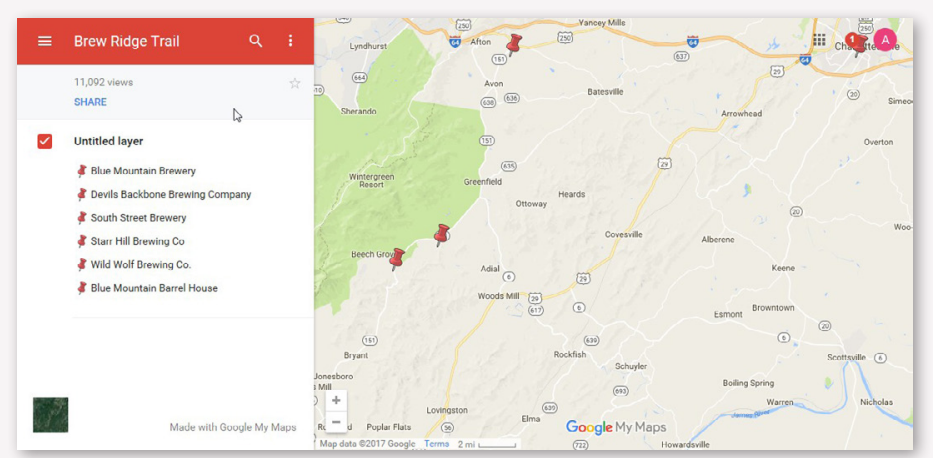

Figure 6. The Brew Ridge Beer Trail (Nelson County Virginia $2017)$ is an example of how interactive maps can create an unbalanced map layout if they are not designed with visual balance in mind.

potential for an unbalanced layout is high. Irregularly shaped states such as Maryland, or regions where several breweries are clustered together in close proximity mapped alongside a few dispersed breweries, present design challenges. The example of the Brew Ridge Trail (Figure 6) displays the location of the breweries with a simple locator pin along the top and side of the map (Nelson County Virginia 2017). The central portion of the page is of little of interest to visitors. This map used simple, geometric symbols, like $49(55.6 \%)$ of all beer trail maps. The remaining $44.4 \%$ used iconic symbols, which were either a pint glass or the individual brewery logo. Coincidentally, the number of balanced/uneven layouts is the inverse of the number of those maps that used geometric versus iconic symbols at every scale. However, there is no relationship between these two codes, as different maps were classified in each category.

The potential for a beer trail to influence the direction of movement or suggested travel routes declined greatly as the region depicted grew in size. Local and regional-scale maps (16 (50\%) and 12 (40\%), respectively) symbolized and labeled main roads or intended paths more often than maps at the state or national scales (6 (24\%) and $0(0 \%)$, respectively). Figure 7 offers an example of map that communicates a trail by simplifying the surrounding areas and highlighting participating breweries. The Astoria Warrenton Chamber of Commerce, the Seaside Visitor Bureau, the Oregon Brewers Guild, and the Oregon Coast Visitor Association created the "Oregon's North Coast Beer Trail" (n.d.). Their website gives viewers a choice of two maps. The first is an interactive web map created by Maplam that allows viewers to zoom in and out on a satellite image. The second, a printable PDF map, has clearly visible features that highlight the location of each
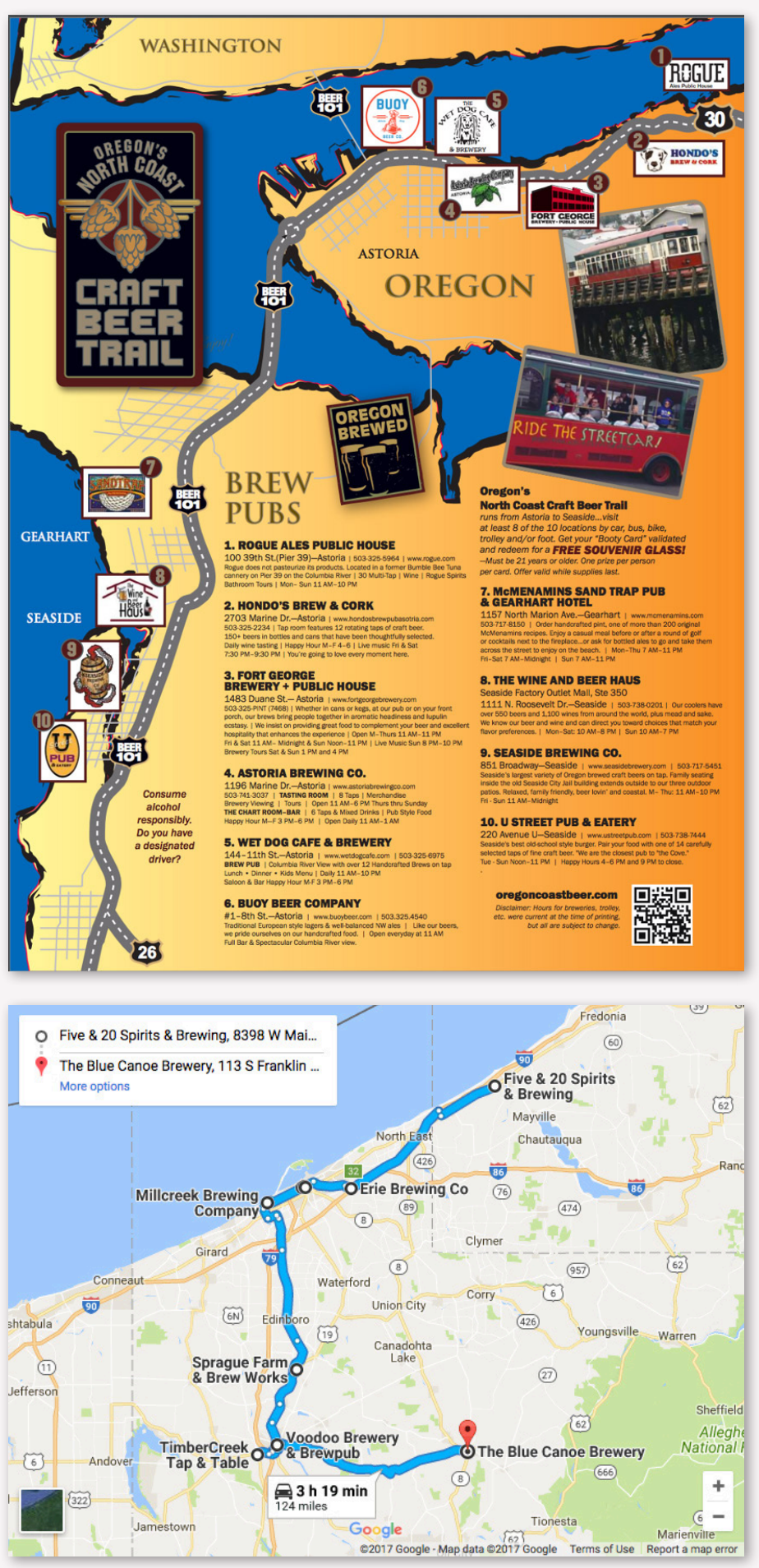

Figure 7. Examples of purposefully designed trails using effective generalization principles to communicate locations of breweries within the North Coast of Oregon region (Astoria Warrenton Chamber of Commerce et al. 2016) and for the Lake Erie Ale Trail (VisitErie 2016).

brewery and the main route. Although an actual "trail" is not drawn, the prominent symbolization of the Coast Road against a simple background focuses the viewer's attention. The color choices, line widths, and the pictorial 
symbols of the breweries' logos construct this space as a regional beer destination. Although the emphasis on travel routes was found more often on static, author-oriented designs, a few interactive maps mapped and highlighted a suggested trail. The Lake Erie Ale Trail (VisitErie 2016) has a 110-mile suggested trail represented with a blue line on Google Maps.

Most maps only advertised breweries on their trail. Despite many tourism agencies suggesting related activities along the trail, the majority did not include any themes including these activities on their map (77.2\% of the total number of maps). Of the twenty maps that did include additional items, wineries and distilleries were the most commonly connected tourist activity. Figure 8 displays two examples of how the ale trails either do not or just barely advertise additional tourism activities. The Hershey Harrisburg Wine Country LLC and Hershey Harrisburg Regional Visitor Bureau (2013) created the "HersheyHarrisburg Craft Beer Country Trail," which clearly identifies each brewery within an approximately 30 to 40 mile region on a shaded relief map, displaying the topography, rivers, and major highways. The accompanying text on the website supports additional tourist activities, but they are not displayed on the map. The website claims these breweries have a vast selection of handcrafted brews surrounded by first-rate attractions and world-renowned restaurants and hotels. The Finger Lakes Beer Trail Marketing and Tourism Associates (2015) created "The Finger Lakes Beer Trail," which promotes New York State as a premier craft beer destination, listing the breweries and displaying them on Google Maps. This map attempts to promote other tourist activities with different colored symbols, yet the extent of items other than the breweries is limited. The map displays 105 breweries and brew pubs and 10 lodging accommodations, but only three restaurants, two retail stores, and two attractions.

Only a handful of beer trails are accompanied by maps that promote the larger tourism region, with a slight increase occurring as the geographic extent of the area depicted increases, from local, to regional, to statewide maps $(6.2 \%$, $10 \%$, and $16 \%$, of maps at each respective scale). Most of these maps characterize the physical landscape, depicting topography, beaches, and mountains. As seen in Figure 8, the design of these maps almost exclusively changes to cartoon-like symbols, fonts with handwritten appearances, and highly generalized locations. The Jacksonville Visitors Bureau prominently promotes the "Beerventure" (Figure 9) as one of the most prominent activities on their official tourism website (n.d.). The map displays the major highways and sections of town, with the labeling of beaches and graphic scale appearing to be lettered by hand. Colored star shapes are used to symbolize the breweries. The map
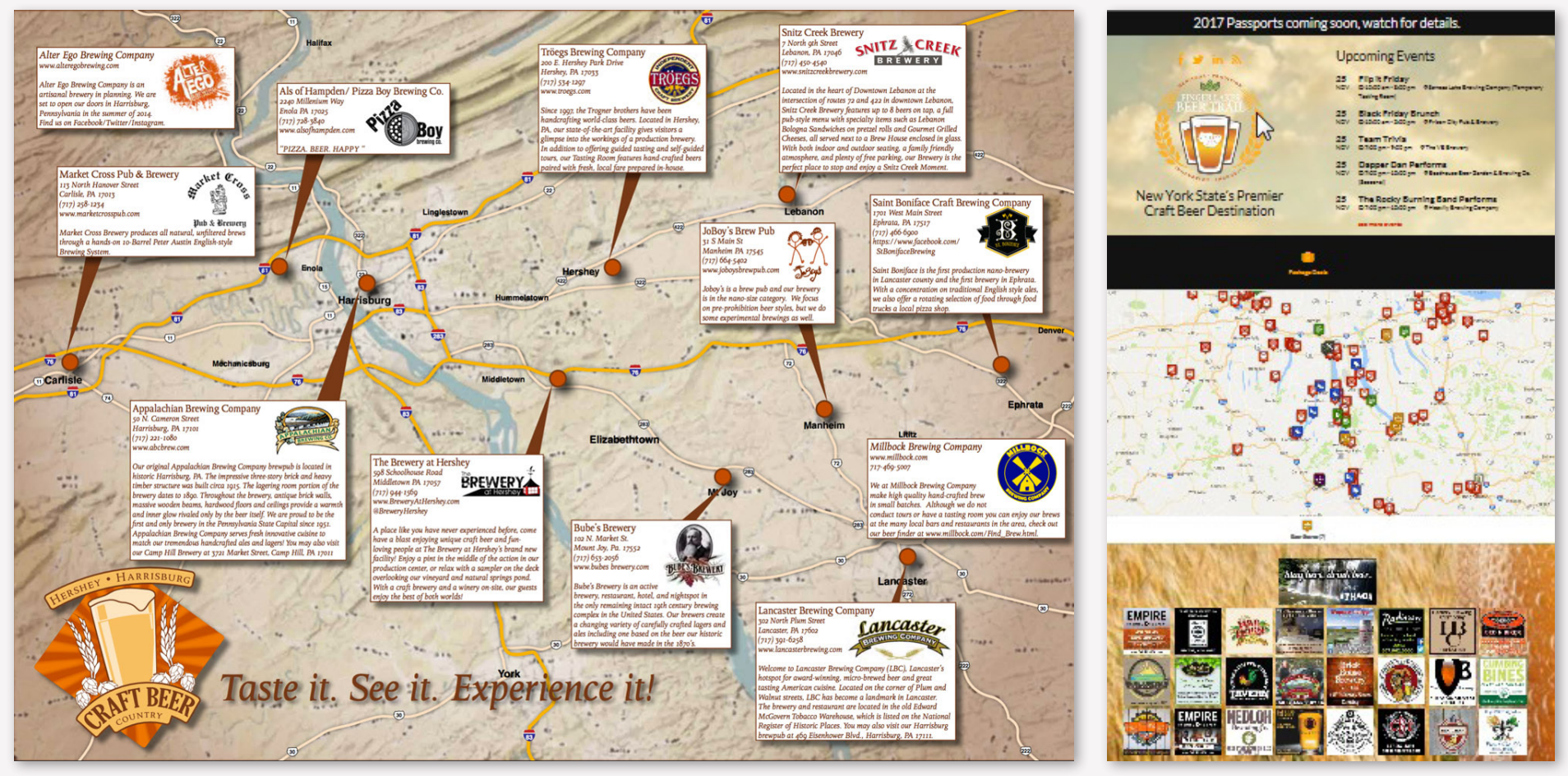

Figure 8. Examples of the absence or limited inclusion of additional tourist activities on trail maps (Hershey Harrisburg Wine Country, LLC and Hershey Harrisburg Regional Visitor Bureau 2013; Finger Lakes Tourism and Marketing 2015). 

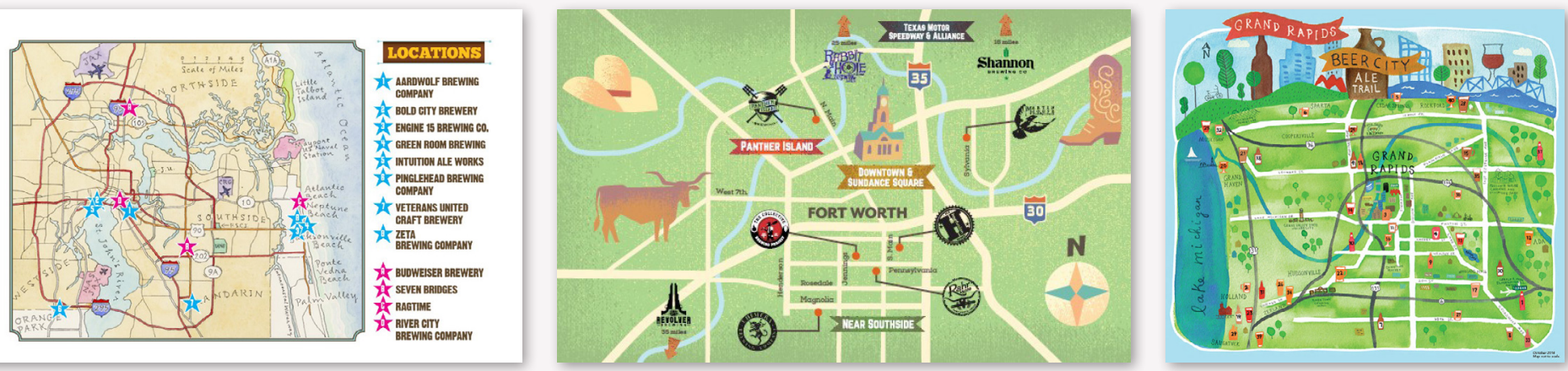

Figure 9. Examples of beer trail maps that promote the larger tourism destination. Jacksonville, FL, Fort Worth, TX, and Grand Rapids, MI, (left to right) utilize cartoon-like symbols and fonts with a handwritten style.

is intended to grab the viewer's attention and provide relative location rather than actual directions to the brewery. The Fort Worth Convention and Visitors Bureau (n.d.) encourages people to download the official "Ale Trail Map" from their website. The map sits amongst links to the individual breweries, an incentive passport program, and "off the trail" promotion of wineries and distilleries. The map has an extremely generalized outline of the city locating the breweries with their individual logos on a few main roads. The surrounding area is displayed with a light green background, the river is symbolized with a smoothed blue line, and several iconic, cartoonish drawings such as a cowboy hat, cowboy boots, and cattle fill the page. The drawings are intended to be characteristic of the region rather than representative of specific tourist destinations. Similarly, the Grand Rapids Convention and Visitor Bureau (2014) encourages people to download their "Beer City Ale Trail" map. This map colorfully and clearly advertises the numerous breweries located in and around the city. The top of the map has a cartoon-like skyline with a few iconic buildings and bridges intermixed amongst trees, a bicycle, a sailboat, and towering beer bottles and beer glasses, implying that beer is deeply connected to the historic and current landscape of the city. A few regional towns and points of interest are drawn on the map, and the text appears to be handwritten. The appearance of stylized trees, watercolor-painted background, lower-case letters for Lake Michigan, and a disclaimer stating "map not to scale" gives the map an inviting, warm, friendly place to visit with a slightly juvenile, cutesy feel.

Of all the beer trails promoted by tourism offices, two maps communicate the location of breweries in addition to other local experiential tourism activities and promote the regional landscape in a well-designed, balanced graphic using symbols, colors, and pictures that are somewhat age-appropriate for the typical craft beer consumer. One example (Figure 10) is the "North Lake Tahoe Ale Trail," map produced by the North Lake Tahoe Chamber (2015). The website describes the large, alpine lake 
that hosts endless adventurous outdoor activities amidst an equally diverse set of breweries. Text and short videos describing recreational activities such as kayaking, paddle boarding, mountain biking, and skiing fill their website along with an interactive ale trail map. The overview map, seen in Figure 9, is colorful and eye-catching, with simplified, iconic symbols for mountain bike trails, road biking trails, hiking trails, kayak/paddleboard trails, ski resorts, and breweries superimposed on a lightly shaded map with subtle isolines indicating the local topography. Major highways, resorts, mountains, rivers, and lakes are symbolized mostly in primary colors, and labeled in white. The background of the legend forms the shape of a beer mug, and the title "Ale Trail" is capped with a sketch of mountains and underlined by paddles. These design techniques connect the regional landscape with the theme of the map, but do not distract from the important points of interest. When map viewers mouse over mapped features, an additional menu appears. Detailed information, descriptions, pictures, videos, links to websites, and hours of operation are provided.

Figure 11 is another example of a map that encourages tourism and promotes attractions near breweries. This map, generated by the Montana Brewers Association (n.d.), encourages viewers to go to the website www.visitMT.com to learn about the great state of Montana and visit one of the state's 60 craft breweries. The map highlights a few major highways and state roads, but draws more attention to the physical landscape by representing the dry plains and the lush mountainous areas. Major rivers, towns, parks, historic points of interest, and outdoor recreation opportunities are mapped. Drawings of wildlife, big-game hunting, fish, and tractors are sketched on the map, but in a more realistic style rather than the previously described cartoon-like images. Pint glasses mark the location of the breweries as the focal point of the map, but the additional eye-catching, aesthetically pleasing, and decorative features encourage the viewer to examine and study the map. The clustering of large symbols over a seemingly small

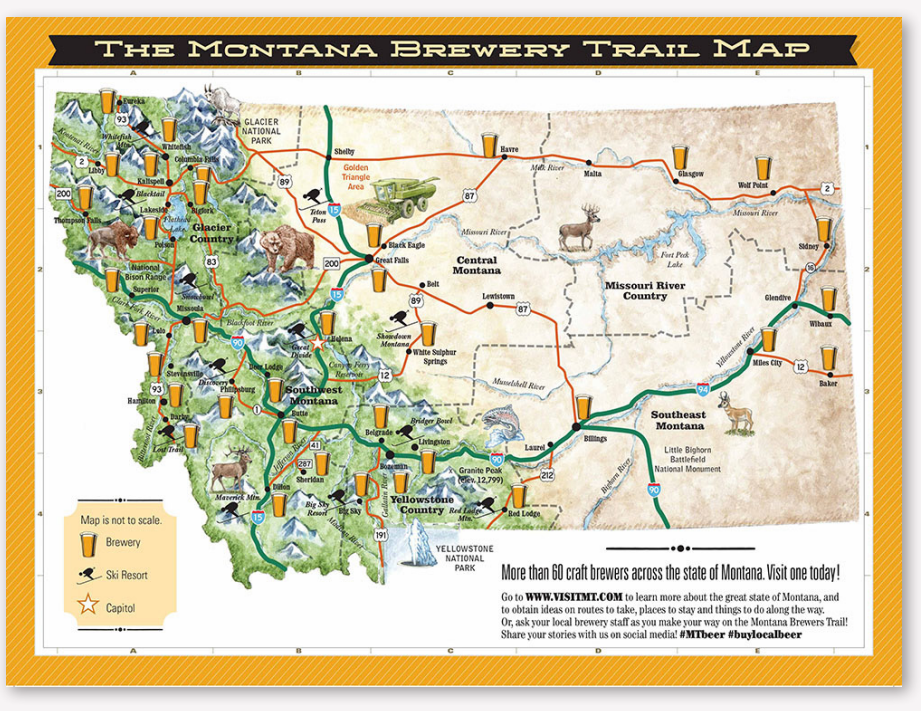

Figure 11. The Montana Brewery Trail Map marks the relative location of breweries within the state while promoting a range of other activities (Montana Brewers Association, n.d.).

area, due to the small map scale, generates a perception that the landscape is brimming with a range of activities in a state permeated with breweries.

The variation in maps found in this study suggests that the majority of maps designed for marketing beer trails emphasize wayfinding to a destination rather than increasing tourism to a region. While most cartographers stress communication, they generally agree that maps have aesthetic functions as well, and those aesthetics will impact how a user interacts with the map (Kent 2012). Additionally, maps should seem to relate to the interests and demography of the target audience, and can be a framework for marketing a sense of place (Warnaby 2008). As seen in the Lake Tahoe map and the Montana map, a well-designed beer trail map can suggest activities that might be of interest to the typical demographic that drinks craft beer. Maps that advertise a region to active, environmentally conscious, millennial males may promote additional stops during the trip, sightseeing, and combining a range of activities along with visiting a craft brewery.

\section{CONCLUSION}

The goAl of THE PROJECT was to assess if beer trails generated by tourism agencies included a map, and if so, what was their intended use, what common design traits they shared, if they represented the regional landscape, and if they promoted other experiential tourism activities that would potentially generate additional benefits to the travel destination. Undeniably, tourism agencies aggressively advertise local breweries as an experiential activity. In most cases, beer trails are as proudly promoted as local parks, museums, historic buildings, festivals, and 
other prominent tourist attractions. Regardless of the geographic extent of the destination, or the distinction of the beer-producing region, beer trails are highly advertised tourist activities.

One hundred beer trails, 88 of which had maps, were identified from national, state, regional, and local tourism agency websites. This study focused on the potential for a map to generate tourism, and thus focused only on beer trails associated with tourism agencies, however it should be noted that many magazines, newspapers, and personal blogs have developed very nice, artistic maps that display a range of other activities. QCA was used to analyze the 88 maps identified for this study.

Maps developed for beer trails on tourism websites, however, are significantly underutilized for marketing purposes, and many do not effectively promote additional travel destinations. The maps rarely represent other tourist amenities, and most are not designed to their full marketing potential. The majority of trail maps that include directions to breweries or promote an actual travel path are generated with Google Maps. Google Maps' purpose is to allow the map user to navigate effectively from point $A$ to point $\mathrm{B}$, usually with the shortest distance and time. The graphic communication and design focus of Google Maps is on the actual streets that enable users to reach their destination. Although multiple routes can be suggested, Google Maps will most often suggest traveling on main roads or highways, yet it is the smaller, back roads in many agritourism areas that are more likely to support additional points of interest, such as fruit stands, pick-yourown farms, smaller villages with historic points of interest, and other local craft shops and businesses. If most people using the internet to view a tourism website are in the initial stages of gathering ideas and planning a trip, designing a map that effectively promotes the general locations of breweries and assists in discovering additional off-thebeaten path activities may potentially generate regional development. In an era of readily available in-car navigation systems and smart phones, communicating what else a visitor can do, eat, or see in an area may be much more important than knowing how to get there.

A handful of maps were purposefully and artistically designed with effective symbolization highlighting the location of breweries, and only a few beer trail maps were designed to focus the viewer's attention on the regional landscapes and additional points of interest. Most of these maps were designed like postcards in the 1950s, with iconic, cartoon-like drawings and highly generalized locations. Admittedly, these bright colors and cartoon drawings are eye-catching, but are slightly unrealistic and juvenile in appearance. The cutesy map designs may not be an effective marketing tool for the typical craft beer drinker: a well-educated male over the age of 35 .

Only two maps, "Lake Tahoe Ale Trail" and "The Montana Brewery Trail Map," highlighted the distribution and locations of breweries, suggest pathways, represent the regional landscape, and promote additional activities using symbols, colors, fonts, and pictures appropriate for the age demographic of their target market audience. Two out of the 88 official trail maps is an exceptionally small proportion, and demonstrates the conspicuous lack of use of map design principles that could harness maps' potential to channel tourists to desired tourist activities. Most of the maps only support wayfinding needs rather than encouraging tourists to travel to and explore other attractions outside or surrounding the destination. Possible future research could examine what aspects of map design are likely trigger specific actions by particular demographics. If a cartographer understood which aspects of design along with what design style, and how many features and themes on a map resulted in the desired map user behavior (visiting additional tourist attractions), then guidelines and best practices could be suggested for experiential tourism maps.

Travel to breweries and consumption of craft beer is part of a much larger farm-to-table movement. Most breweries fully embrace their connections with the local history and geography and engage in sustainable practices that support other local farmers and businesses. Experiential tourism and craft beer are both witnessing an economic resurgence. Mass-produced beer companies have engaged in overt forms of advertising for decades; tourism agencies should seek assistance from cartographers to advertise craft beer companies as well. A well-designed, effective map could promote not only the lure of craft beer, but also persuade visitors to travel to a region, enjoy the local environs, explore back roads, engage in a range of experiential activities, and in short, influence the success of a region. 
Adirondack Regional Chambers of Commerce. n.d. "Adirondack Craft Beverage Trail and Map." Accessed November 4, 2016. http://adkcraftbev.com/map.

Ashworth, Mick. 2011. "Making Maps Work for Visitors.” Interpretation Journal 16(2): 14-16.

Astoria Warrenton Chamber of Commerce, Seaside Visitor Bureau, The Oregon Brewers Guild, and Oregon Coast Visitor Association. n.d. "Oregon's North Coast Beer Trail.” Accessed December 3, 2016. http://oregoncoastbeer.com/home-menu.

Baginski, James, and Thomas L. Bell. 2011. "UnderTapped? An Analysis of Craft Brewing in the Southern United States." Southeastern Geographer 51(1): 165-185. doi: 10.1353/sgo.2011.0002.

Bailey, Heidi, David Smaldone, Gregory Elmes, and Robert Burns. 2012. "Geointerpretation: The Interpretive Potential of Maps?” Journal of Interpretive Resources 12(2): 45-59.

Batzli, Samuel. 2014. "Mapping United States Breweries 1612 to 2011" in The Geography of Beer: Regions, Environment, and Societies, edited by M. Patterson and N. Hoalst-Pullen, 31-43. Dordrecht, Netherlands: Springer-Science. doi: 10.1007/978-94-007-7787-3_4.

Carmichael, Barbara A., and Donna M. Senese. 2012. "Competitiveness and Sustainability in Wine Tourism Regions: The Application of a Stage Model of Destination Development of Two Canadian Wine Regions." in The Geography of Wine: Regions, Terroir, and Techniques, edited by P. H. Doughtery, 159-178. New York: Springer Science. doi: 10.1007/978-94-007-0464-0_9.

Caroll, Glenn R., and Anand Swaminatham. 2000. "Why the Microbrewery Movement? Organization Dynamics of Resource Partitioning in the U.S. Brewery Industry." American Journal of Sociology 106(3): 715-762.

Colton, John W., and Glyn Bissix. 2005. "Developing Agritourism in Nova Scotia: Issues and Challenges." Journal of Sustainable Agriculture 27(1): 91-112. doi: 10.1300/j064v27n01_06.
Del Buono, Amanda. 2015. "Crafting the American Culture.” Beverage Industries November 2015, 30-38.

Del Casino, Jr., Vincent J., and Stephen P. Hanna. 2000. "Representation and Identities in Tourism Spaces." Progress in Human Geography 24(1): 23-46. doi: 10.1191/030913200673388638.

Discover Lehigh Valley. n.d. "Drink Till You're Merry.” Accessed December 2, 2016. http:// lehighvalleyaletrail.com.

eBizMBA Guide. 2016. “Top 15 Most Popular Search Engines.” Accessed October 26, 2016. http://www. ebizmba.com/articles/search-engines.

Everett, Sally, and Susan L. Slocum. 2013. "Food and Tourism: An Effective Partnership? A UK-Based Review." Journal of Sustainable Tourism 21(6): 789-809. doi: 10.1080/09669582.2012.741601.

Experience Columbus. n.d. "The Columbus Ale Trail." Accessed December 2, 2016. http://www.cbusaletrail. com.

Felberbaum, Michael. 2015. "Bud Campaign Highlights Rift Between 'Big Beer,' Craft.” Boston Globe, February 6, 2015. Accessed January 3, 2017. http://www.

bostonglobe.com/business/2015/02/06/budweisercampaign-highlights-rift-between-big-beer-craft/ FpCjis62CULcQdnLr3dYaI/story.html.

Feeney, Alison E. 2015. "The History of Beer in Pennsylvania and the Current Growth of Craft Breweries." The Pennsylvania Geographer 53(1): 25-43. doi: 10.1016/j.ccs.2017.03.001.

Ferreira, Sanette L., and Retha Muller. 2013. "Innovating the Wine Tourism Product: Food-And-Wine Pairing in Stellenbosch Wine Routes." African Journal for Physical Health Education, Recreation and Dance September (Supplement 2): 72-85.

Finger Lakes Beer Trail Marketing and Tourism. 2015. “Finger Lakes Craft Beer Trail." Accessed August 17, 2017. https://fingerlakesbeertrail.com/content. 
Fort Worth Convention and Visitors Bureau. n.d. "Fort Worth Ale Trail.” Accessed December 12, 2016. https://www.fortworth.com/aletrail.

Fuggle, Lucy. 2016. "70 Travel \& Tourism Statistics to Know About in 2016 (Trends Report)." Accessed August 17, 2017. https://www.trekksoft.com/en/blog/ travel-tourism-stats-2016.

Grand Rapids Convention and Visitor Bureau. 2014.

“Beer City Ale Trail." Accessed January 3, 2017. http:// www.experiencegr.com/things-to-do/beer-city/ beer-tour.

Grant, Lesley A., and C. Peter Keller. 1999. "Content and Design of Canadian Provincial Travel Maps." Cartographica 36(1): 51-61, doi: 10.3138/2t07-6264-1394-1820.

Halladay, Jessie. 2012. “Tourists Drawn to Distilleries, Breweries.” USA Today, March 19, 2012.

Hershey Harrisburg Wine Country, LLC and Hershey Harrisburg Regional Visitor Bureau. 2013. "HersheyHarrisburg Craft Beer Country Trail.” Accessed January 3, 2017. http://www.hersheyharrisburgbeer. com.

Hoalst-Pullen, Nancy, Mark W. Patterson, Rebecca Anna Mattord, and Michael D. Vest. 2014. "Sustainability Trends in the Regional Craft Beer Industry" in The Geography of Beer: Regions, Environment, and Societies, edited by M. Patterson and N. Hoalst-Pullen, 109116. Dordrecht, Netherlands: Springer-Science, doi: 10.1007/978-94-007-7787-3_11.

Hojman, David E., and Philippa Hunter-Jones. 2012. "Wine Tourism: Chilean Wine Regions and Routes." Journal of Business Research 65: 13-21, doi: 10.1016/j. jbusres.2011.07.009.

Jacksonville Visitors Bureau. n.d. "Plan Your Beerventure: Jax Ale Trail.” Accessed January 3, 2017. http://www. visitjacksonville.com.
Kent, Alexander J. 2012. "From a Dry Statement of Facts to a Thing of Beauty: Understanding Aesthetics in the Mapping and the Counter-Mapping of Place." Cartographic Perspectives 73: 37-60. doi: 10.14714/ cp73.592.

MacEachren, Alan M. 1994. Some Truth with Maps: A Primer on Symbolization $\Xi$ Design. Washington: Association of American Geographers.

Maine Brewers' Guild. 2013. "The Maine Beer Trail: Visit Breweries, Get Rewarded.” Accessed November 3, 2016. http://mainebrewersguild.org/wp-content/ uploads/2013/05/ME-Beer-Trail-Jan-2016.pdf.

Maine Office of Tourism. 2016. "The Maine Beer Trail.” Accessed November 17, 2016. https:// visitmaine.com/things-to-do/dining-and-nightlife/ the-maine-beer-trail.

Martin, James W. 2011. "Mapping an Empire: Tourist Cartographies of the Caribbean in the Early Twentieth Century." Early Popular Visual Culture 91(1): 1-14. doi: 10.1080/17460654.2011.544110.

Massachusetts Office of Travel and Tourism. 2014. "Massachusetts Craft Brewers Passport Program.” Accessed November 4, 2016. http:// www.massvacation.com/blog/2014/04/ traveling-the-massachusetts-craft-brewers-trail.

McLaughlin, Ralph B., Neil Reid, and Michael S. Moore. 2014. "The Ubiquity of Good Taste: A Spatial Analysis of the Craft Brewing Industry in the United States." in The Geography of Beer: Regions, Environment, and Societies, edited by M. Patterson and N. HoalstPullen, 131-154. Dordrecht, Netherlands: SpringerScience. doi: 10.1007/978-94-007-7787-3_13.

Monmonier, Mark. 1996. How to Lie with Maps. Chicago: The University of Chicago Press. doi: 10.7202/022356ar.

Montana Brewers Association. n.d. "The Montana Brewery Trail Map.” Accessed January 6, 2017. http:// montanabrewers.org/trail-map. 
Mowen, Andrew J., Alan R. Graefe, and D. A. Graefe. 2013. "Research Brief: Results from the Pennsylvania Craft Beer Enthusiast Study." Unpublished report to the Brewers of Pennsylvania Association.

Muehlenhaus, Ian. 2011a. "Genealogy That Counts: Using Content Analysis to Explore the Evolution of Persuasive Cartography." Cartographica 46(1): 28-40. doi: 10.3138/carto.46.1.28.

2011b. "Another Goode Method: How to Use Quantitative Content Analysis to Study Variation in Thematic Map Design." Cartographic Perspectives 69: 7-30. doi: 10.14714/cp69.28.

Nelson County Virginia. 2017. "Brew Ridge Trail." Accessed on March 29, 2017. http://bit.ly/2yoPVXH.

North Carolina Craft Brewers Guild. n.d. "North Carolina Beer Trail.” Accessed November 4, 2016. http://ncbeer.org/map/.

North Lake Tahoe Chamber. 2015. "North Lake Tahoe Ale Trail.” Accessed January 6, 2017. https://www. gotahoenorth.com/things/north-lake-tahoe-ale-trail.

Reid, Neil, Ralph B. McLaughlin, and Michael S. Moore. 2014. "From Yellow Fizz to Big Biz: An American Craft Beer Comes of Age." Focus on Geography 57(3): 114-125. doi: 10.1111/foge.12034.

Roth, Robert, E., Kevin S. Ross, and Alan M. MacEachren. 2015. "User-Centered Design for Interactive Maps: A Case Study in Crime Analysis.” ISPRS International Journal of Geo-Information 4: 262-301, doi: 10.3390/ijgi4010262.

Schnell, Steven M. 2011. "The Local Traveler: Farming, Food, and Place in State and Provincial Tourism Guides, 1993-2008." Journal of Cultural Geography 28(2): 281-309. doi: 10.1080/08873631.2011.583441.

Sonoma County GIS. n.d. "Sonoma County Craft Beverage Map.” Accessed November 11, 2016. http:// sonomaedb.org/storymaps/beermap.
Suchan, Trudy, and Cynthia A. Brewer. 2000. "Qualitative Methods for Research on Map Making and Map Use." The Professional Geographer 52(1): 145-154. doi: 10.1111/0033-0124.00212.

Travelindiana.com. n.d. "South Shore Brewery Trail.” Accessed December 2, 2016. http:// www.travelindiana.com/agritourism/ south-shore-brewery-trail.

Tuan, Yi-Fu. 1991. "Language and the Making of Place: A Narrative-Descriptive Approach." Annals of the Association of American Geographers 18(4): 684-696. doi: 10.1111/0033-0124.00212.

Veeck, Gregory, Deborah Che, and Ann Veeck. 2006. "America's Changing Farmscape: A Study of Agricultural Tourism in Michigan." The Professional Geographer 58(3): 235-248. doi: 10.1111/j.1467-9272.2006.00565.x.

Visit California. 2017. “The Craft Beer Boom.” Accessed August 9, 2017. http://www.visitcalifornia.com/ feature/craft-beer-boom.

Visit Denver. n.d. "Denver Beer Trail." Accessed December 2, 2016. http://www.denver.org/ restaurants/denver-bars-clubs/denver-beer-trail.

VisitErie. 2016. “Lake Erie Ale Trail.” Accessed November 4, 2016. http://www.lakeeriealetrail.com/ drive-the-trail.

Visit Spokane. 2016. "Inland Northwest Ale Trail." Accessed April 7, 2016. http://inlandnwaletrail.com.

Visit St.Petersburg/Clearwater. 2016. "The Gulp Coast beer trail." Accessed April 9, 2017. http://www. visitstpeteclearwater.com/gulp-coast-craft-beer-trail.

Visit USA. 2016. "Craft Beer Trail." Accessed April 7, 2017. https://www.visittheusa.com/trip/ craft-beer-trail.

Warnaby, Gary. 2008. "Why Place Marketers Should Understand Cartography: Future Avenues for Research." Journal of Place Management and Development 1(2): 214-226. doi: 10.1108/17538330810890022. 
Wilcox, Gary B. 2001. "Beer Brand Advertising and Market Share in the United States: 1977 to 1998."

International Journal of Advertising 20(2): 149-168. doi: 10.1080/02650487.2001.11104884.

Whitwell, Stuart. 2014. "Branding in the Craft Beer Industry.” Just Drinks.com. Accessed November 2, 2017. https://www.just-drinks.com/analysis/focusbranding-in-the-craft-beer-industry_id113070.aspx.
Wyoming Beer Trail. 2016. "Wyoming Beer Trail." Accessed April 2, 2017. https://static1.squarespace. com/static/566c3d960e4c116bdc03015a/t/5 889f8b6893fc0fc035493e4/1485437119100/ Wyoming+Beer+Trail+Map.pdf.

Wood, Denis. 1992. The Power of Maps. New York: Guilford Press.

\section{APPENDIX}

1. Adirondack Craft Beverage Trail and Map: adkcraftbev.com

2. Alabama Beer Trail alabama.travel/road-trips/ alabama-beer-trail-flight-one

3. Ale Trail Jackson County, NC www.discoverjacksonnc.com/attractions/ brewery-trail

\section{Anaheim Beer Hop} visitanaheim.org/explore/anaheim-brewery-trail

5. Atlanta Metro Craft Brew Flavor Tour www.exploregeorgia.org/itineraries/georgia-craft-breweries-and-distilleries-flavor-tour

6. Arizona Brewery Tours www.azbrew.com

7. Arkansas Brewery Trails www.arkansas.com/taste/breweries-distilleries/ trails

8. Asheville NC Ale Trail ashevillealetrail.com

9. Bend Ale Trail www.visitbend.com/things-to-do/ Bend-Ale-Trail

10. Berkshire Beer and Cider Trail www.berkshirefarmandtable.org/ taste-trails-beer-cider

11. Bloomington Local Craft Ale Trail www.bloomingtonaletrail.com

12. Brew Ridge Trail brewridgetrail.com
13. Boise Ale Trail boisealetrail.com

14. Boulder Ale Trail boulderaletrail.org

15. Brattleboro Beer Trail www.vermontbrewers.com/brewery-trails/ brattleboro-trail

16. Brew Grass Trail www.kentuckytourism.com/dining/trails/ brewgrass

17. Brews in the Gorge www.breweriesinthegorge.com

18. Central Coast Beer Trail www.centralcoastbeertrail.com

19. Central Florida Ale Trail centralfloridaaletrail.com

20. Central PA Tasting Trail www.visitpennstate.org/eat/ central-pa-tasting-trail

21. Coastal VA Beer Trail www.virginia.org/listings/ WineriesAndBreweries/CoastalVABeerTrail

22. Columbus Ale Trail www.cbusaletrail.com

23. Connecticut Beer Trail ctbeertrail.net

24. Cooperstown Beverage Trail www.cooperstownbeveragetrail.com

25. Craft Beer Trail www.visittheusa.com/trip/craft-beer-trail 
26. Cumberland Valley Beer Trail www.visitcumberlandvalley.com/things-to-do/ food-wine-beer/beer-trail

27. Daytona Beach Ale Trail www.daytonabeach.com/things-to-do/ale-trail

28. Delaware Beer, Wine, and Spirits Trail www.visitdelaware.com/beer-wine-spirits-trail

29. Delmarva's Wine and Ale Trail toastourcoast.com

30. Denver Beer Trail www.denver.org/restaurants/denver-bars-clubs/ denver-beer-trail

31. Downtown Phoenix Urban Trail dtphx.org/things-to-do/aletrail

32. Duluth Ale Trail www.duluthbeertrail.com

33. Edible Santa Fe Craft Brewers Trail Map www.ediblenm.com/craft-brewers-trail-map

34. Eugene Ale Trail www.eugenecascadescoast.org/eugene-ale-trail

35. Evansville Craft Beer Trail drinkin.beer/tag/evansville-craft-beer-trail

36. Fayetteville Ale Trail fayettevillealetrail.com

37. Finger Lakes Beer Trail fingerlakesbeertrail.com/content

38. Flagstaff-Grand Canyon Ale Trail www.flagstaffaletrail.com

39. Fort Worth Ale Trail www.fortworth.com/aletrail

40. Grand Rapids Ale Trail www.experiencegr.com/things-to-do/beer-city/ beer-tour

41. Grapes and Grains Tour www.grapesandgrainstrail.com

42. Gulp Coast: St. Pete/Clearwater's Craft Beer Trail www.visitstpeteclearwater.com/ gulp-coast-craft-beer-trail

43. Heart of New York Craft Beverage Trail www.oneidacountytourism.com/beverage-trail
44. Hill Country Craft Beer Trail hillcountrycraftbeertrail.com/trails

45. Howard On Top Trail www.visithowardcounty.com/howard-on-tap/ trail-stops

46. Hudson Valley Beer Trail www.hudsonvalleybeertrail.com

47. Huntsville Craft Beer Trail www.huntsville.org/restaurants-breweries/ downtown-huntsville-craft-beer-trail

48. Inland Northwest Ale Trail inlandnwaletrail.com

49. Iowa Beer Trail www.iowabeer.org/\#iowabeertrails

50. Jacksonville Ale Trail www.visitjacksonville.com/jax-ale-trail

51. Johnston County, NC Beer Wine and Shine Trail www.beerwineshinetrail.com

52. Kalamazoo Beer www.discoverkalamazoo.com/drink/beer/ kalamazoo-brewery-map/\#/gallery/recent

53. Kansas Brewery and Distilleries www.travelks.com/things-to-do/ arts-entertainment/breweries-and-distilleries

54. Kansas City Ale Trail www.kcaletrail.com

55. Knoxville Ale Trail knoxvillealetrail.com

56. Lake Erie Ale Trail www.lakeeriealetrail.com

57. Lake Tahoe Ale Trail www.gotahoenorth.com/ north-lake-tahoe-ale-trail-map

58. Lancaster Ale Trail www.discoverlancaster.com/lancaster-county-trails/ale-spirits-trail.asp

59. Lehigh Valley Ale Trail www.discoverlehighvalley.com/blog/post/thelehigh-valley-ale-trail-our-top-five-local-microbrew-bars 
60. LocCo Ale Trail

www.visitloudoun.org/things-to-do/

loco-ale-trail

61. Louisiana Brewery Tour

www.visittheusa.com/experience/

louisianas-brewery-trail

62. Louisiana Libations

libations.louisianatravel.com/breweries

63. Maine Beer Trail Passport

mainebrewersguild.org/

new-maine-beer-trail-passports-are-here

64. Maryland Craft Breweries

www.visitmaryland.org/

breweries-wineries-and-distilleries

65. Massachusetts Craft Brewers Trail www.mass.gov/agr/massgrown/culinary_tourism/docs/brewery-brochure.pdf

66. Middletown Tasting Trail www.middtastingtrail.com

67. Minnesota's North Shore Beer Trail www.exploreminnesota.com/travel-ideas/ trekking-minnesotas-north-shore-beer-trail

68. Mississippi Brewery Trail www.visitmississippi.org/app/webroot/files/ Mississippi\%20Brewery\%20Trail\%202015.pdf

69. Missoula Spirit and Ale Trail www.missoulaspiritandaletrail.com

70. Montana Ale Trail www.visitmt.com/montana-stories/montana-pressroom/story-ideas/ale-trail.html

71. NE TN SW VA Brewly Noted Beer Trail brewlynotedbeertrail.com

72. Nelson 151 Trail www.virginia.org/listings/wineriesandbreweries/ nelson151trail

73. North Carolina, A Tasty Craft Brew Tour www.visitnc.com/trip-idea/a-tasty-craft-brewtour-north-carolina-style

74. North Dakota Beer and Wine Trail www.ndtourism.com/articles/ north-dakota-beer-and-wine-trail
75. Oakland Ale Trail www.visitoakland.com/things-to-do/ oakland-ale-trail

76. Oregon North Coast Craft Beer Trail oregoncoastbeer.com/home-menu

77. PDX Ale Trail www.travelportland.com/directory/pdx-ale-trails

78. Philadelphia Craft Beer Trail www.visitphilly.com/itineraries/philadelphia/ the-breweries-brewpubs-and-craft-beer-trail-ofgreater-philadelphia

79. Pittsburgh Ale Trail pittsburghaletrail.com

80. Placer County Wine and Ale Trail forknroadproductions.com/wine--ale-trail-map. html

81. Raleigh Beer Trail www.visitraleigh.com/raleighbeertrail

82. Richmond Beer Trail www.visitrichmondva.com/drink/ richmond-beer-trail

83. Rogue Valley Ale Trail www.southernoregon.org/rogue-valley-ale-trail

84. Santa Barbara Ale Trail www.santabarbaraaletrail.beer

85. Santa Cruz Beer Trail www.santacruzbeertrail.com

86. Shenandoah Beerwerks Trail beerwerkstrail.com

87. Shore Craft Beer shorecraftbeer.com/brewery-trails

88. Sonoma County Beer Trail www.sonomacounty.com/articles/beer-trail-itinerary-explore-breweries-sonoma-county

89. South Shore Indiana Brewery Trail www.southshorecva.com/ssbt

90. Southwest Florida Ale Trail www.swflaletrail.com

91. Summit Brew Path www.summitbrewpath.com 
92. Sunrise Side Wine and Hops Trail www.us23heritageroute.org/wine_and_hops.asp

93. Susquehanna Ale Trail www.yorkpa.org/things-to-do/ susquehanna-ale-trail

94. Tampa Bay Ale Trail www.tampabayaletrail.com

95. Tap Trail www.taptrail.com
96. Tri-Valley Beer Trail visittrivalley.com/tri-valley-beer-trail

97. Western Massachusetts Beer Trail www.valleyvisitor.com/western-mass-beer-trail. html

98. Wilmington Ale Trail wilmingtonaletrail.com

99. Wyoming Beer Trail www.wyomingbeertrail.com 